\title{
Winds of Consciousness: An Analysis of Revolutionary Narratives and Praxis
}

\author{
YiShan Lea ${ }^{1}$
}

This paper explores revolutionary pedagogy. It is an ethnographical inquiry on revolutionary praxis. Specifically the aims are to scrutinize the people's contacts with power to the emerging states of liminality. The interests of the study focus on the contexts wherein individuals commence to make decision to engage in political structural transformation. Narratives, diaries, biographies, interviews, and documentary videos/films are reviewed. Two political mobilizations are studied, one is the Cuban Revolution in the 1950's and the other the Neo-Zapatistas in 1994. [Article copies available for a fee from The Transformative Studies Institute. E-mail address: journal@transformativestudies.org Website: http://www.transformativestudies.org (C2014 by The Transformative Studies Institute. All rights reserved.]

KEYWORDS: Wolf, Winnicott, Freire, Liminality, Transitional Phenomena, Social Mobilization, Revolutionary Praxis, Revolutionary Narrative.

\section{INTRODUCTION}

This paper intends to provide revolutionary narratives accounting for the phenomena of political mobilization, participation, and organization. The tradition of psychoanalysis calls for attention to "specific quality experiences" in the development of identity. Sociocultural theories of education and social reconstructivists emphasize life as narrative resulting from dynamic interactions among social, cultural, and personal factors that, in turn, influence life construction and identity formation.

\footnotetext{
${ }^{1}$ YiShan Lea, Ed.D., is an assistant professor of Bilingual Education at Central Washington University, Washington, USA. Her research interests include Freirean pedagogy, narrative analysis, critical theory and practice. Address correspondence to: YiShan Lea, Central Washington University, 400 E. University Way, Ellensburg, Washington 98926; e-mail: leay@cwu.edu.
} 